\title{
Performance of Quoted and Non-quoted Companies in the Europe ${ }^{\#}$
}

\author{
Tomáš BUUS*
}

\section{Introduction}

The differences in performance of quoted and non-quoted companies are not sufficiently resolved in contemporary literature (and if they are, then mainly with respect to the quality of financial statements). According to our opinion, this gap in corporate finance research needs to be filled, because it can help to explain some transmission mechanisms of quotation/non-quotation to performance, with respect (but not limited to) agency cost. We also consider the differences between quoted and nonquoted companies to be important from the point of view of financial planning and business valuation as the profitability ratios ${ }^{1}$ can be used to predict future profit growth (e.g. Fama and French, 2000) or investor's expectations about future growth. The possibility of differences in performance of quoted versus non-quoted companies is evident:

1. A number of authors point out the difference between excellent performance of companies in pre-IPO phase and poor performance in post-IPO phase (e.g. Jain and Kini, 1994), which is even worse in comparison with performance of companies that have been quoted for a longer time.

2. Possibility of principal-agent conflicts can result in a better reported performance not only if this possibility exists on the highest management levels, but also if it emerges in a company (in general) due to more vertical management structure (Durand and Vargas, 2003). This observation has been explained by a really better

\# This paper was prepared in the framework of research plan Development of Accounting and Financial Theory and its Application in Practice from Interdisciplinary Point of View (registered number MSM 6138439903).

* Ing. Tomáš Buus, Ph.D. - assistant professor; Department of Corporate Finance and Valuation, Faculty of Finance and Accounting, University of Economics, Prague, W. Churchill Sq. 4, 13067 Prague 3, Czech Republic; <buust@vse.cz>.

1 Return on assets, return on equity or return on invested capital (capital employed). 
performance and also by a choice of accounting methods and different regulation of accounting (between quoted and non-quoted companies).

3. The private benefits of control can be exploited more easily in nonquoted companies, especially when owners are members of management board at the same time.

4. Finally the possible differences in performance between quoted and non-quoted companies can be result of wider public knowledge of the quoted companies compared to non-quoted companies. However, this is just our thesis because we have found evidence neither in results of empirical nor theoretical research.

We suppose that we will find some evidence that there is a difference between performance of quoted and non-quoted companies, but we suppose that the differences can be marginal in most cases, while the main factors influencing differences in performance are managementborn and emerge form competitive advantages of companies. We suppose to find some general differences mainly on the level of indebtedness, cash management and maybe wage costs.

Due to several factors that could possibly explain the observed difference between some characteristics of quoted compared to nonquoted companies, this study is aimed generally on description of the above stated differences.

The scope of literature dealing with relationships between quotation and performance of a company is quite small. Most of the articles concentrate on the performance around the date of quotation. Degeorge and Zeckhauser (1993) find that at the reverse LBO the performance of a company is extraordinarily good, contrary to the post-quotation period, when the researched companies show poor performance. Jain and Kini (1994) even find positive relationships between the share of the original (pre-IPO) owners after IPO and the company's performance in the postIPO period. As we show later, these issues can be addressed to creative accounting, or misuse of depreciation and write-off policies as well as to IPO timing choice by insiders (original owners), which have better information compared to outsiders. 
However, the conditions specific to quoted companies should (ceteris paribus) in a long-term lead to better performance. Among such specifics of quoted companies can be different accounting rules, agency problems and lower information asymmetry between insiders and outsiders (compared to the non-quoted companies).

We could expect a lower indebtedness of quoted companies compared to non-quoted ones, due to the easier access to external sources of equity (Mull and Winters, 1997), but we could also expect lower liquidity (Valentincic and Mramor, 2000). It can be shown that these features of quoted companies emerge from higher variance of cash flow, higher cost of additional financing and longer time needed for acquisition of new capital (Buus, 2004) for the non-quoted companies. Quoted and nonquoted companies can even in specific cases choose different pricing policies. This is closely connected with quality of corporate governance and with the fact that immoral behavior is not usually followed by share price fall at the non-quoted companies (Schargrodsky, 2001). Very few authors address this kind of differences in relation to quotation. Among the few who state that the quoted companies are weakly more efficient in some cases, are Durand and Vargas (2003). Nevertheless, they attribute this finding (using $2 \times 2$ model based on agency theory) to the idea that non-quoted companies with more vertical structure (multilayer ones) can achieve even better results than the quoted ones to better control in multilayer owner-managed firms. Quite complex study addressing the problems of performance characteristics of quoted vs. non-quoted companies is (Evans and Poa and Rath, 2005), but the study is based on comparison between quoted companies and companies to be de-listed. The companies, which were de-listed, have had excellent performance, mainly high cash flow, high growth rates (statistically significant), high indebtedness and higher $\mathrm{R} \& \mathrm{D}$ expenses and also higher share of management ownership.

As we can see the most of the cited studies concentrate on the agency cost problems (either explicitly or implicitly), but the difference in the main financial characteristics between quoted and non-quoted companies in general has not been researched yet, as far as we know. 


\section{Reliability of financial statements}

Looking at the accounting regulation we could see some signs that IAS/IFRS are in some aspects more conservative than most of the national accounting standards across Europe, because of:

1. depreciation, amortization and/or impairment are considered more rigorously in IAS/IFRS - on one hand they allow revaluation upwards to a fair value, if a business chooses so, but the revaluation upwards never affects profit \& loss statement and therefore influence the net income;

2. IFRS/IAS do not recognize some items that are recognized in CAS, mainly change in stock of products and semi-finished products or "revenues" from production used in a company;

3. IAS/IFRS do not allow to capitalize research expenses;

4. IAS/IFRS require capitalization of leasing payments (therefore the leased property is recognized as an asset and the present value of future leasing payments as a liability).

Finally we have to say that probably the main reason is that accounting was in the Europe historically used mainly as a base for corporate income tax evaluation, which implies that there was not primary need for conservatism.

On the other hand IAS/IFRS allow the business more freedom in some aspects, especially in terms of revaluation, depreciation and impairment. Comparing the conservativeness of accounting itself has not any sense as the agents (management) can chose from a wide range of accounting methods able to distort earnings or level them out (Tucker and Zarowin, 2006). For this purpose they can chose for example the methods of fixed assets valuation, depreciation, creation of (hidden) reserves and use of accrual items generally (which is empirically confirmed by Basu, 1997) or even way of stock valuation (Dyl, 1989). But the question is always the effect, i.e. the ability of the market to unveil this mimicking behavior $^{2}$ and also the penalties to managers either in form of leaving

2 For measurement of the effect of unexpected earnings is used so called Earnings Response Coefficient (ERC) defined as $R=\alpha+\beta \cdot($ ern $-u)+\varepsilon$, where $R$ are expected earnings (yield), $\alpha$ is yield of the benchmark, $\beta$ is ERC, $(e r n-u)$ are unexpected earnings (unexpected yield) and $\varepsilon$ is the stochastic variable (e.g. Collins and Kothari, 1989). Nevertheless many modifications of this basic definition of ERC are used. 
their seats or worse outlooks for better future engagement (Desai and Hogan and Wilkins, 2006). Are there any differences between the quoted and non-quoted companies from this point of view?

Kwon and Newman and Suh (2001) prove theoretically that under certain (we think acceptable) conditions that the existence of principalagent relationship (management is different from owners) is the determinant of the requirement for conservativeness of financial statements, whereas the need of conservativeness grows with the falling penalty for managers for distortion of financial statements. In the case of non-quoted companies is the separation of management and ownership rather less usual and from this also follows a lower probability of information asymmetry and smaller need for prudence, which is theoretically proven by the above mentioned paper by Kwon and Newman and Suh. On the other hand Dyl (1989) came to different conclusions on the empirical basis - finds that managers of companies with the separated management and ownership use less conservative methods (in the case of stock valuation it is $\mathrm{FIFO}^{3}$ ), whereas managers of closely held corporations use rather conservative methods $\left(\mathrm{LIFO}^{4}\right)$. The different conclusions of the above cited papers are results of different assumptions - Dyl (1989) examines the companies using similar accounting standards and from this point of view the determination of accounting policies lies in hands of managers (agents), Kwon and Newman and Suh (2001) assume that the level of conservatism is determined by shareholders (principals). Finally Beeks and Pope and Young (2004) conclude that the amount of outsiders in the controlling body of corporation does not have any statistically significant influence on accuracy and timeliness of positive announcements, but significantly raises timeliness and frequency of negative announcements. These conclusions regarding the influence of corporate governance on the level and frequency of financial scandals (e.g. Enron, Parmalat) show that the German management model can in certain degree eliminate the risk of potential of financial statements distortion (Coffee, 2005).

3 First in First out, where the disbursed stock is valued by the price of the first acquired stock. It is apparent that in the inflationary economy this leads to lower cost and higher profits (which is not of course valid in the deflationary environment or environment with stable purchasing power of monetary unit).

4 Last in First out, the meaning of this shortcut is similar to the one mentioned in previous footnote. 
In fact the level of prudence is mostly determined by the penalty and quality of auditor. Desai and Hogan and Wilkins (2006) find (on US data) that most of the managers who used "creative accounting", lost their work, have difficulties in finding new job and when they found it, they used to get significantly lower remuneration than was the average. This threat is relevant rather in the case of quoted companies. The non-quoted companies have usually common management and ownership and so we can't imagine manager-owner firing himself. This is one of the reasons why we should be more careful when using and analyzing the financial statements of the non-quoted companies - especially in the case of sale of the company or business. Conservative accounting methods commonly used in non-quoted companies can provide lot of space for creation of hidden reserves or their later disbursement. Several papers point at this risk, finding the plunge of performance in post-IPO period compared to pre-IPO period. Let us mention at least (Jain and Kini, 1994) or (Hertzel et al., 2002), who found the worse performance not only at IPO's, but also at private placements. Any change of the accounting methods in the case of non-quoted companies should be therefore closely followed even though with the reputation of auditor and length of his relationship with client grows also the trustworthiness of the financial statements for investors (Ghosh and Moon, 2005).

What partial conclusions can be then done about the reliability of financial statements of quoted and non-quoted companies (at least based on the above short analysis)? From one point of view the statements of quoted companies should be more conservative because of the more conservative regulation IFRS, on the other hand we find there a principalagent relationship with information asymmetry. This problem can be to a certain degree softened by a higher quality of audit and by penalties for distortion of financial statements by managers, but it is not entirely eliminated, as Dyl (1989) shows. Newer research (among others Beeks and Pope and Young, 2004) indicates that we can expect better times from this point of view.

Although Bagnoli and Watts (2005) prove analytically, and Boulton and Smart and Zutter (2007) empirically confirm that users of the financial statements are able to filter the distortions, we think that on the base of the financial scandals in last eight years (Enron, Parmalat, KPN Qwest) that caution is necessary, even though most of the scandals had American roots (Coffee, 2005). 
Unfortunately it is quite difficult to make any simple conclusion; we can just mention higher risk of change of accounting methods before IPO, divestition, sale of a business, or of share in a company. These risks have roots in higher level of hidden reserves and probably lower quality of audit in the case of non-quoted companies. ${ }^{5}$ Also the fact that better postIPO performance is usually connected with higher share of the original owners in the company in the post-IPO period (Jain and Kini, 1994) points at the information asymmetry. The reason could be (among other factors) that in average the performance is by $8.2 \%$ better on the operational level (EBIT) and by $6.5 \%$ better as measured by CF/Assets. But the manipulation of financial statements seems to be limited as the pre-IPO performance determines chance to survive at the stock exchange in subsequent years (Peristiani and Hong, 2004).

What are then the differences in performance of quoted and nonquoted companies? It seems that the up-to date literature does not resolve this problem or at least the comparison is made for special cases (pre- and post-IPO, reverse LBO's), but not for the differences between non-quoted and quoted companies in general. Is it possible that a wider publicity of quoted companies means an advantage for them in marketing? Or does the principal-agent relationship between shareholders result in different strategy of market value maximization (e.g. publicly announce the as good numbers as possible versus minimize the corporate income tax paid and hide the potential profitability of industry from competitors)? Apparently we will not be able to answer these questions, however the results of empirical research presented in this paper could be a step towards understanding of differences between quoted and non-quoted companies.

\section{Model(s)}

The evidence of differences in performance of quoted and non-quoted companies in terms of market indicators is quite unified in the sense that quotation leads to drop in performance et vice versa. The explanation could be several folds:

1. Managers and majority owners chose the most suitable time to list or de-list shares of their companies from the point of view of the stock

5 Higher level of hidden reserves would signalize also lower EBIT margin at the nonquoted companies. 
market bubbles and crashes so that they list shares at the peak and delist at the bottom of the market (of course only several companies). Evidence about IPO waves (see e.g. Nofsinger, 2005 or Lowry, 2003, p. 24) supports this theory, although sometimes the explanation of the evidence is different.

2. Companies use hidden reserves (asset undervaluation and liabilities overvaluation) in times shortly before quotation (cp. Kirchmaier and Grant, 2005, p. 235, note 12) as it raises profits and feeds high profit growth expectations (Penman, 2003).

3. There is a difference in accounting methods. The accounting methods used by quoted companies are stricter and also soundness of auditor must be higher than at non-quoted companies.

4. Quoted companies perform worse in terms of accounting profitability. This would be also supported by the stricter accounting regulation. We can see easily that this is not viable concept, because share of quoted companies on the economy would shrink if the above statement were true, whereas evidence from numerous stock markets and long-term periods proves the opposite (Ritter, 2005, p. 494).

As most of the companies on the stock market are not newcomers, but established ones, we can rather expect that they will perform better than the non-quoted ones. The theorem we testis that due to agency relationship managers in quoted companies have to deliver better performance than managers-owners, who often do not have the dilemma whether to report higher profit or pay higher taxes and can concentrate on cash flow maximization. But the results might also signalize whether the dispersed ownership is more efficient in choice of managers (voting by feet) or some other advantage or disadvantage of listing/de-listing. If being quoted were so disadvantageous, non-quoted companies would probably deliver better performance.

As we have simple aim to identify differences between performance of quoted and non-quoted companies, the hypotheses can be tested either using regression methods (panel regressions with respect to use of panel data) or cluster analysis. The first one would show immediately the difference, the second one rather statistical property of the data clusters. Most of the previous studies have used performance of shares on the stock market as the measure of performance. However we are naturally 
limited in use of this measure, because non-quoted companies are not in most cases object of frequent trade, therefore we have to rely solely on accounting measures of performance.

With respect to structure of data and previous literature we assumed to be necessary to distinguish several dimensions of data: time, country and industry.

First of all it is usual to distinguish data with respect to time in our panel data set. To be more precious we should probably control for some other factors, which could be stronger determinants in nationally and economically heterogeneous European economy (more closely to the economic heterogeneity of Europe write Clark and van Wincoop, 2001). The commercial habits could also affect performance measures (and some other financial ratios) as either above mentioned Clark and van Wincoop (2001) or Brown and Soybel and Stickney (1994) show. The individual characteristics and regulation of accounting in particular countries is important mostly for the non-quoted companies as the quoted ones have to follow IFRS.

The literature on industry effects in performance measures (mostly accounting ones) goes from Porter's hypothesis that "the structural characteristics of industries were the primary determinants of performance" (Hawawini and Subramanian and Verdin, 2003, p. 2) over the initial empirical works (Schmalensee, 1985) to the newest ones (Lieu and Chi, 2006). The most of the papers since 1990 till now report significant industry effects (for short overview see e.g. Lieu and Chi, 2006), but they found much stronger segment effects and also significant corporate effects. Moreover Hawawini and Subramanian and Verdin (2003) show that several outliers cause most of the intra-industry variance of performance and after controlling for these extreme over- or underperformers the industry effects are much stronger (account for 12 $30 \%$ of performance variance). It is also worth mentioning, that for the market measures (i.e. valuation multiples) Alford (1992) or Schreiner (2007) find a use of more narrowly specified peer groups to be much more accurate in terms of pricing errors. The above overview of literature signalizes that we probably should use 2-digit SIC code distinction proxy to control for industry effects.

A little complication is that we have 4-dimensional panel (country, year, industry, companies), whereas in one dimension (industry peer 
group) we have about 60 of possibly mutually heterogeneous groups of data if we used 2-digit SIC code distinction, in the other about 20 groups (country). Therefore we use three dummy vectors to control for country, year and industry effect. Furthermore we possibly need to control for:

1. Sales; the level of sales significantly influences negotiation power. This phenomenon was found by many researchers, mostly with respect to suppliers and in the case of horizontal mergers - compare (Snyder, 1995), (Fee and Thomas, 2003) or (Bykowsky and Kwasnica and Sharkey, 2005). In some cases the horizontal integration also improves position towards customers (Chipty and Snyder, 1999), whereas in the case of vertical integration is the effect doubtful and depends on the elimination/strengthening of monopoly/monopsony of particular company (Machlup and Taber, 1960). Clarke and Davies and Waterson (1984) point out that multibusiness enterprises reach higher profitability as a consequence of stronger market position, not only because of better efficiency.

2. Number of subsidiaries; firstly as a consequence of revaluation of some items in balance sheets of consolidated companies during consolidation, depreciation can grow and therefore the profit margin would fall as well as ROIC (return on invested capital), ROA (return on assets) and ROE (return on equity). The reason is also that in inflationary environment (there was stable, though low, inflation in the Europe in the recent years) fixed assets are being revalued upwards during consolidation. The higher share of consolidated companies on consolidated balance sheet, the more significant effect (ceteris paribus). Secondly vertical integration (which probably grows with growing number of subsidiaries) should lead to lower agency cost, thus better performance (cp. Durand and Vargas, 2003).

We will test differences between quoted and non-quoted companies for the usually used financial ratios as margins, profitability, turnover or cash flow coverage (etc.). The used regression model then has the following form:

$$
\begin{aligned}
& Y=\beta_{0}+\overline{\beta_{N A C E}} \cdot \overline{N A C E}+\overline{\beta_{Y E A R}} \cdot \overline{Y E A R}+\overline{\beta_{C T R Y}} \cdot \overline{C T R Y}+ \\
& \beta_{R E V} \cdot R E V+\beta_{\text {QUOTED }} \cdot Q U O T E D+\beta_{\text {SUBS }} \cdot S U B S+\varepsilon \text { ' } \\
& \text { is endogenous variable (see Tab.1), }
\end{aligned}
$$




$\begin{array}{ll}\beta, \text { resp. } \bar{\beta} & \begin{array}{l}\text { are regression coefficients, resp. vectors of } \\ \text { regression coefficients, } \\ \text { represents dummy vector for 2-digit NACE } \\ \text { classification, } \\ \overline{Y E A R}\end{array} \begin{array}{l}\text { is a dummy vector for years 2001-2005, } \\ \text { is a dummy vector for country, where the } \\ \text { company has it's seat (however we were not } \\ \text { able to control for multinationals), } \\ \text { represents revenues expressed in thousands }\end{array} \\ \text { REV } & \begin{array}{l}\text { EUR, } \\ \text { is dummy on quotation (1 for quoted, 0 for } \\ \text { non-quoted), } \\ \text { is number of subsidiaries, } \\ \text { represents residuals. }\end{array} \\ & \end{array}$

The examined endogenous variables, which were the most common financial ratios based on accounting variables, are defined in Tab.1.

Tab. 1: Definition of the endogenous variables

\begin{tabular}{|l|l|l|}
\hline Variable & Variable notation & Unit $^{6}$ \\
\hline Net asset turnover, i.e. revenues / net assets & Net_assets_turn & \\
\hline CF margin (cash flow / revenues) & CF2Rev & $\%$ \\
\hline CFROE (cash flow / net assets) & CFROE & $\%$ \\
\hline $\begin{array}{l}\text { Stock turnover (days), } \\
\text { i.e. stock · 365 / turnover }\end{array}$ & Stock_turn & Days \\
\hline $\begin{array}{l}\text { Collection period } \\
\text { (receivables · 365/turnover) }\end{array}$ & Collection_per & Days \\
\hline $\begin{array}{l}\text { Credit period } \\
\text { (payables · 365/turnover) }\end{array}$ & Credit_period & Days \\
$\begin{array}{l}\text { Current ratio (short-term receivables plus } \\
\text { cash in bank and in the hand, the whole } \\
\text { divided by short-term payables) }\end{array}$ & Current_ratio & \\
\hline $\begin{array}{l}\text { Liquidity ratio (cash in bank and in the } \\
\text { hand, the whole divided by short-term } \\
\text { payables) }\end{array}$ & Liquidity_ratio & \\
\hline
\end{tabular}

6 Empty if no particular unit. 


\begin{tabular}{|l|l|l|}
\hline Variable & Variable notation & Unit $^{6}$ \\
\hline $\begin{array}{l}\text { Solvency ratio, which is represented by } \\
\text { ratio of cash flows before changes of } \\
\text { working capital to short-term payables }\end{array}$ & Solvency_ratio & \\
\hline EBIT margin (EBIT / revenues) & EBIT_Margin & $\%$ \\
\hline EBITDA margin (EBITDA / revenues), & EBITDA_Margin & $\%$ \\
\hline Return on assets & ROA & \\
\hline Revenues growth rate & & \\
\hline Interest coverage & Interest_cover & \\
\hline Personnel cost /revenues & PersC_Rev & $\%$ \\
\hline
\end{tabular}

Source: Author's assessment

\section{Data}

We used data from AMADEUS database. The original structure consisted of data for all NACE Rev. 1.1 sections (of which for some subsections there were no data), the distribution of data over NACE Rev. 1.1 sections was approximately even. Companies, for which the data were available, were seated in 40 European countries (after the lower described controlling for some improper data, 26 countries remained). The data range was since 2001 till 2005, which captures most of the last economic cycle in Europe. The original data comprised of 21094 companies with financial statement data for years 2001 to 2005 (some of them not for all years). We included only companies, which are not controlled (more than $50 \%$ share) by any majority shareholder (or shareholders acting in concert). That implies that only data from consolidated financial statements (if there was duty to consolidate) were used. About 1969 companies were singles with no subsidiary, the others had up to 1647 subsidiaries (!).

As it could have been expected, some of the companies, which were not quoted, had an influential shareholder, who was quoted and conversely some non-quoted companies had quoted subsidiaries. We excluded these companies to avoid blur in results due to translation of cost of capital and other quoted companies properties onto the non-quoted ones in our sample (for detailed discussion see Buus, 2007). A careful reader would ask why we did not exclude quoted companies with nonquoted subsidiaries. The first reason was that efficient financial markets 
should tend to the lowest cost of capital and if the main provider of capital in the holding structure has lower cost of capital due to its quotation (no illiquidity discount), then this low-cost-of-capital effect spreads also to the non-quoted subsidiaries (again see Buus, 2007). Furthermore managers of the quoted companies are not owners of the non-quoted subsidiaries, but in many cases they are also appointed in the boards of the subsidiaries, therefore acting as agents towards the subsidiaries too. Moreover most of the quoted companies are frequently holding headquarters (in our sample only 48 had no subsidiaries), thus exclusion of these companies would lead almost to inability to carry out any reliable analysis.

We also excluded companies with incomplete record in given year, except for the revenues growth rate, because the regression on revenues growth rate as endogenous variable was done separately. Because of it we had 2 different samples - for research into differences in revenues growth rate consisting of 51274 company-years, and for all the other financial ratios mentioned above, consisting of 16383 company-years. We assumed that the difference in size of the sample and one difference in data handling (in the case financial ratios we excluded incomplete records, whereas in case of revenue growth we could have computed only growths for years 2002 to 2005) do not result in systematic distortion of results. In fact, as we had large samples and the revenue-growthregression sample was larger, thus closer to the whole population sample, the dichotomy would mean problems only from the point of view of interpretation of relationship between growth and margin (lower margins could mean lower prices, thus competitive advantage in gaining market share et vice versa). But as we will see further, no significant relationship between revenue growth and quotation was found.

A short look at some of the descriptive statistics shows that the quoted companies tend to be much larger than non-quoted ones, tend to have more subsidiaries and also have significantly different medians (averages) for some of the financial ratios. But for return on assets (ROA), liquidity ratio and solvency ratio we can reject the hypothesis that the means are equal, at $5 \%$ confidence level.

Due to the construction of model described in section 3 above we are able to control for influence of size and number of subsidiaries, but the differences in size and number between quoted and non-quoted preclude use of cluster analysis. 
Tab. 2: Descriptive statistics of the endogenous variables

\begin{tabular}{|c|c|c|c|c|}
\hline & \multicolumn{2}{|c|}{ Not quoted } & \multicolumn{2}{|c|}{ Quoted } \\
\hline & Average & Median & Average & Median \\
\hline Revenues & 136724.18 & 42063.00 & 2362425.76 & 254144.00 \\
\hline Subsidiaries & $\begin{array}{r}8.31 \\
\end{array}$ & 4.00 & 77.21 & 31.00 \\
\hline Current_ratio & 1.60 & 1.30 & 1.76 & 1.47 \\
\hline Liquidity_ratio & 1.06 & 0.90 & 1.20 & 1.03 \\
\hline Solvency_ratio & 33.12 & 29.56 & 42.83 & 42.23 \\
\hline ROA & 5.44 & 4.10 & 5.20 & 5.68 \\
\hline Interest_cover & 16.27 & 3.38 & 17.59 & 4.34 \\
\hline Stock_turn & 35.94 & 8.81 & 33.31 & 9.08 \\
\hline Collection_per & 67.04 & 54.00 & 60.58 & 56.00 \\
\hline Credit_period & 50.81 & 40.00 & 35.97 & 31.00 \\
\hline Net_assets_turn & 6.74 & 3.13 & 2.41 & 1.72 \\
\hline PersC_Rev & 14.76 & 11.94 & 23.41 & 22.44 \\
\hline CF2Rev & 6.15 & 4.35 & 8.38 & 7.68 \\
\hline EBIT_Margin & 4.49 & 3.31 & 6.43 & 5.65 \\
\hline EBITDA_Margin & 8.13 & 6.12 & 11.64 & 10.11 \\
\hline CFROE & 7.75 & 1.28 & 10.43 & 4.17 \\
\hline
\end{tabular}

\begin{tabular}{|l|c|c|}
\cline { 2 - 3 } \multicolumn{1}{c|}{} & t-test p-value & Units (Empty if no special unit) \\
\hline Revenues & $\mathrm{x}$ & $1000 \mathrm{EUR}$ \\
\hline Subsidiaries & $\mathrm{x}$ & \\
\hline Current_ratio & $0.0000 \%$ & \\
\hline Liquidity_ratio & $0.0000 \%$ & \\
\hline Solvency_ratio & $0.0000 \%$ & \\
\hline ROA & $19.7620 \%$ & \\
\hline Interest_cover & $29.6639 \%$ & \\
\hline Stock_turn & $10.2572 \%$ & Days \\
\hline Collection_per & $0.0000 \%$ & Days \\
\hline Credit_period & $0.0000 \%$ & Days \\
\hline Net_assets_turn & $0.0000 \%$ & \\
\hline PersC_Rev & $0.0000 \%$ & $\%$ \\
\hline CF2Rev & $0.0000 \%$ & $\%$ \\
\hline EBIT_Margin & $0.0000 \%$ & $\%$ \\
\hline EBITDA_Margin & $0.0000 \%$ & $\%$ \\
\hline CFROE & $0.1540 \%$ & $\%$ \\
\hline
\end{tabular}

Source: Amadeus database, author’s calculation 


\section{Results}

While searching for suitable models we excluded exogenous variables, which could cause multicolinearity (variance inflation factors $>$ 10), and also exogenous variables, which were not statistically significant (using two-sided t-test at $0.10 \mathrm{p}$-value). ${ }^{7}$ The results of OLS regression (using robust HC3 standard error estimates - see (MacKinnon and White, 1985), chapter 5, though heteroskedasticity in standard errors is not necessarily our case) are shown in Tab. 3. Because of quantity of exogenous variables we show only regression coefficients for quotation dummy and regression constant. Most of the models explaining endogenous variables have little explanatory power. We can see that there are probably much stronger determinants of particular financial ratio value (corporate-level determinants), than quotation or country of seat. However, most models show statistical significance of quotation and in several cases, like solvency ratio or ratio of personnel cost to revenues, models explain substantial part of endogenous variable variance.

Although the results are not unambiguous about the fact, which companies perform better, we can say that in the examined period at the examined geographical location some interesting differences were found (for details, see Tab. 3). For the understanding of the results and constant values it should be noted, that constant is an estimate for records with following parameters: country = Ukraine, year 2005, NACE 93 (Other service activities, which include washing and dry-cleaning, hairdressing, funeral services, wellness services and othere services n.e.c.), non-quoted companies, no subsidiaries, revenues $=0$ EUR. Thus the estimates of constant can be sometimes quite extreme (as not many companies are of the size to into the sample covered by the version of AMADEUS database we used).

7 We used Gretl statistical software (open source). 
Tab. 3: Differences between quoted and non-quoted companies OLS results; for variable definition please see Tab.1 above

\begin{tabular}{|l|r|r|r|r|}
\hline Dependent variable & Constant & \multicolumn{1}{c|}{ Quoted } & \multicolumn{1}{c|}{ P-Value } & \multicolumn{1}{c|}{$\mathbf{R}^{\wedge} \mathbf{2}$} \\
\hline Net_assets_turn & 12.7377 & -1.83548 & 0.00000 & 0.05833 \\
\hline CF2Rev (\%) & 5.82521 & 1.00525 & 0.00003 & 0.13452 \\
\hline Stock_turn & 51.6887 & -7.83825 & 0.00038 & 0.07932 \\
\hline Collection_per & 60.2861 & 8.74202 & 0.00000 & 0.22933 \\
\hline Credit_period & 42.5063 & $\mathrm{NSS}^{8}$ & $\mathrm{NSS}$ & 0.24812 \\
\hline Current_ratio & 1.65784 & 0.103954 & 0.02878 & 0.06135 \\
\hline Liquidity_ratio & 1.02889 & 0.0978992 & 0.00000 & 0.05992 \\
\hline Solvency_ratio (\%) & 45.8258 & 5.74417 & 0.00000 & 0.15947 \\
\hline EBIT_Margin & 5.46200 & 1.27824 & 0.00000 & 0.06349 \\
\hline EBITDA_Margin & 12.8722 & 2.40005 & 0.00000 & 0.14267 \\
\hline Interest_cover & 33.5767 & $\mathrm{NSS}$ & $\mathrm{NSS}$ & 0.01286 \\
\hline PersC_Rev & 21.0676 & 2.52581 & 0.00000 & 0.30959 \\
\hline ROA & 6.73106 & -0.495376 & 0.03099 & 0.02848 \\
\hline CFROE & 0.71070 & 3.09618 & 0.00006 & 0.16534 \\
\hline Rev_growth & 19.6652 & $\mathrm{NSS}$ & $\mathrm{NSS}$ & 0.03382 \\
\hline
\end{tabular}

Source : Amadeus database, author's calculation

We have found the following relationships: Net asset turnover is higher in the case of non-quoted companies, by almost 2 turnovers. The constant in regression model is high, however, we have to see that it is estimate for NACE 93 with naturally high turnover. The intuition tells us that quoted companies seem to have higher capitalization. One could object that quoted companies tend to be in more capital-intensive industries or to be in capital-intensive industries, but the industry-specific factors were (hopefully) captured by NACE subsection dummy vector. The turnover difference could have been caused partially by higher collection period at the quoted companies (by almost 9 days), while probably better inventory management at the quoted companies (lower turnover period by almost 8 days) offsets this influence. The regression coefficient for quotation dummy is not significant in the case of credit period as well as interest coverage, indicating that regarding the use of

8 NSS $=$ Not statistically significant at the $10 \%$ level of significance. 
debt, quoted and non-quoted companies follow similar financing strategy (at least in the terms of these financial ratios).

Using larger data sample (29 157 company-years) from the same location and years, but using less accurate NACE classification, Buus and Brabenec and Strouhal (2007) found significant difference between credit periods, in magnitude of 20 days. Their model has explained less variance of the endogenous variable ( $\mathrm{R} 2=18 \%$ ), probably due to less accurate NACE classification. Going further in the questions about financing policy, we found that quoted companies are more conservative in terms of liquidity (keeping approx 10\% higher cash than non-quoted ones) and also that they have higher solvency ratio (coverage of liabilities by cash flow before changes in working capital) by approx. $6 \%$ points. This could be not only due to higher EBIT margin and EBITDA margin of the quoted companies (1.2\% and $2.4 \%$ points respectively), it also fits the finding about higher cash flow margin and CFROE at the quoted companies (1\%, resp. 3.1\%). These are significantly higher and the models we used explained about $13 \%$ to $16 \%$ of endogenous variable variance. On the other hand ROA was slightly lower for quoted companies, which draws a question about hidden reserves policy and the conservatism of accounting standards and managers. Finally share of personnel cost on revenues was found to be higher by $2.5 \%$ points at the quoted companies, than at the non-quoted ones and the model captured more than $30 \%$ of the endogenous variable variance.

With respect to hidden reserves and earnings management we examined evolution of difference between median ROA of quoted and non-quoted companies during the time in our sample and also between median of (Depreciation + Amortization)/Revenues. The results are mixed, as difference between ROA diminished during economic downturn (2001, 2002) and grew during economic growth (2004 - 2005), while for (Depreciation + Amortization)/Revenues no pattern was found. Either are the differences in earnings management insignificant or some other instruments than depreciation and amortization methods were used. Having taken look at CF2Rev, we found the same pattern, as for ROA, but of larger magnitude (see Fig.1). Therefore we think that there is no significant difference between earnings management outcomes at the quoted companies and at the non-quoted companies. 
Fig. 1: Evolution of difference in ROA, CF2Rev and D+A_Rev (depreciation+amortization divided by revenues) between quoted and non-quoted companies during $2001-2005$

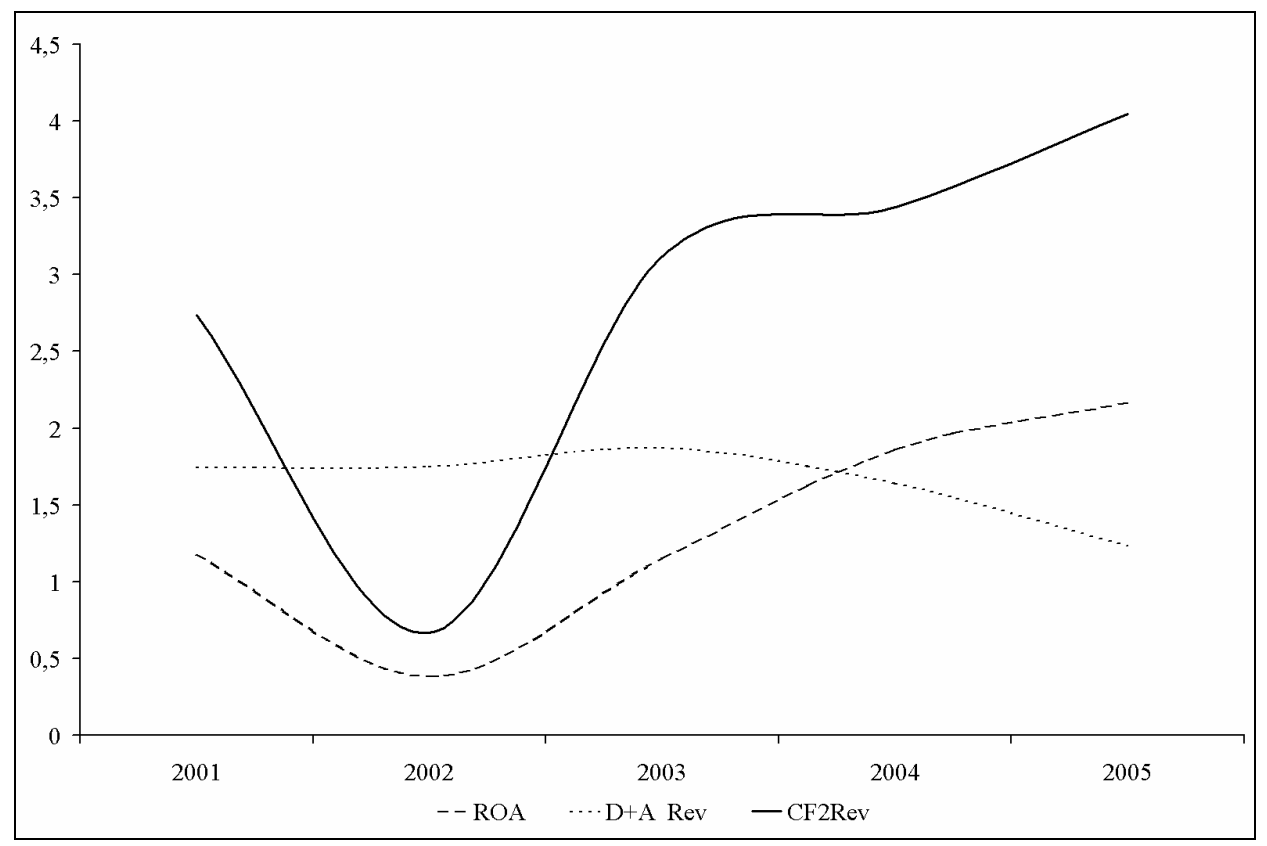

Source : Amadeus database, author's calculation

\section{Discussion \& conclusions}

Literature that deals with differences between quoted and non-quoted companies at the level of financial ratios (based on accounting numbers) has not been frequent recently. The papers we have found, examine mostly differences in performance during pre-IPO and post-IPO periods. Several studies also take a look at owner-controlled and managementcontrolled firms (e.g. Holl, 1975). Some studies concluded on worse performance in post-IPO periods. But capitalization and profits of quoted companies have grown faster than the rest of the economy (Ritter, 2005). Is it the cause investors' optimism or do the quoted companies perform systematically better and if they do, then why? The evidence depends on method. Jagannathan and McGrattan and Scherbina (2000) show that equity premia have fallen. Some other, like Mehra and Prescott (2003) find growing equity premia using historical total equity returns, which we consider not to be correct treatment of the problem, with respect to the 
nature of equity valuation principles, they evidently use in their study. Contemporarily questions have been raised about reliability of financial statements, conservatism of accounting rules, agency problems, etc. The literature we found did not satisfy us so we could say any opinion prevailed. The empirical investigation we made could bring some light into these problems.

Our findings suggest that quoted companies perform better during the times of economic growth as well as under conditions of economic downturn. The positive difference in favor of quoted companies was found not only in profit (i.e. EBIT and EBITDA) margins and ROA, but also in the case of cash flow ratios (i.e. CF margin and CFROE). Quoted companies also seem to hold more cash than their non-quoted counterparts and if we took into account the magnitude of differences for CFROE and solvency ratio (solvency ratio regression coefficient almost twice as high as for CFROE), we can see indirect indices that findings of Mull and Winters (1997) can not be confirmed in the case of book values of debt and equity, rather quoted companies tend to have lower book D/E. Higher personnel cost in the case of quoted companies are outweighed by the benefits in the form of higher cash flows and profits. Our findings suggest that although IFRS, which are obligatory for quoted companies, are deemed more conservative, in fact there does not have to be any difference in earnings management and conservatism between quoted and non-quoted companies, which, again, is not equal, but indicates, similar conclusions for IFRS and local accounting standards. Our findings also have implications for agency theory, as some of the non-quoted companies are owner-managed, but most of the quoted ones have professional management, who are agents with respect to company owners. This agency relationship might have some influence on better results of quoted companies, although also some other causes could be hypothesized (widespread knowledge and better public image due to closer media attention to quoted companies). Finally we should mention that above the indirect indices, which our results provide, they have direct impact on conduction of financial analysis and business valuation. The expected long-term performance of quoted companies should be higher than the population average, as well as liquidity and cash flow.

The regression models we used contained large dummy vectors, therefore we could not disclose all regression coefficients, but above the differences between quoted and non-quoted companies we have found significant differences in credit period and collection period among different 
countries. Among these regional differences we should mention long credit and collection periods for countries at the south of the Europe and France, but much shorter in the case of transitive European economies, northern European countries and Great Britain (differences approximately 30 - 60 days).

Our study has several limitations. Firstly, although we could find some link between quotation and ownership (agency), we distinguished primarily between quoted companies and those, which weren't quoted. One can see that this criterion is not equivalent to the previously mentioned one. Secondly, the models explained only insignificant part of the ratio variance in the case of some financial ratios, but the regression coefficient of the quotation dummy was statistically significant. This can be attributed to the size of sample, which is advantageous as we can consider the differences to be generally observable, but on the other hand it increases significance of regression coefficients even though they would be insignificant for smaller samples. One should be very careful when using our results for ROA and current ratio, from this point of view. Contrary, very significant are differences in CF margin, CFROE and personnel cost (all the mentioned ratios were higher in case of quoted companies). Another limitation is that we haven't linked our empirical analysis directly to any theoretical concept (but it is probably useful as contribution indirectly showing some direction for further research in several areas. Finally one should take into account that our results are based on the whole-Europe sample, whereas there could be large differences between e.g. southern and northern Europe or between developed countries and countries in transition. Finally we did not conduct analysis of all financial statement items, but we rather concentrated on the most important financial ratios. Therefore it is not evident, whether worse performance of non-quoted companies is exogenous or endogenous (even though we controlled for most variables that could influence the differences, including size and NACE subsection). We have to admit that further research in this area is undoubtedly needed to explain our findings.

\section{References}

[1] Alford, A. W. (1992): The Effect of the Set of Comparable Firms on the Accuracy of the Price-Earnings Valuation Method. Journal of Accounting Research, 1992, vol. 30, no. 1, pp. 94-108. 
[2] Bagnoli, M. - Watts, S. G. (2005): Conservative Accounting Choices. Management Science, 2005, vol. 51, no. 5 pp. 786-801.

[3] Basu, S. (1997): The conservatism principle and asymmetric timeliness of earnings. Journal of Accounting \& Economics, 1997, vol. 24, no. 1, pp. 3-37.

[4] Beeks, W. - Pope, P. - Young, S. (2004): The Link between Earnings Timeliness, Earnings Conservatism and Board Composition: Evidence from the UK. Corporate Governance, 2004, vol. 12, no. 1, pp. 47-59.

[5] Boulton, T. J. - Smart, S. B. - Zutter, C. J. (2007): Earnings Quality and International IPO Underpricing. [on-line], Social Science Research Network, $8^{\text {th }}$ March, 2007, [cited $4^{\text {th }}$ September, 2008], $<$ http://ssrn.com/abstract=972694>.

[6] Brown, P. R. - Soybel, V. E. - Stickney, C. P. (1994): Comparing U.S. and Japanese Corporate-Level Operating Performance Using Financial Statement Data. Strategic Management Journal, 1994, vol. 15, no. 1, pp 75-83.

[7] Buus, T. (2004): Management and financing of working capital (in Czech: Řizení a financování pracovniho kapitálu). Praha, University of Economics, Prague, 2004. Seminal work. Unpublished.

[8] Buus, T. (2007): Multibusiness companies valuation (in Czech: Oceňování koncernů). Praha, University of Economics, Prague, 2007. Dissertation thesis.

[9] Buus, T. - Brabenec, T. - Strouhal, J. (2007): Application of the Modern Methods of Valuation for Non-Listed Companies (in Czech: Aplikace modernich metod oceňováni v připadě nekotovaných společností - pracovni sešit). Praha, Oeconomica, 2007.

[10] Bykowsky, M. M. - Kwasnica, A. M. - Sharkey, W. W. (2005): Buyer Size and Bargaining Power: An Experimental Analysis [online]. University Park, Pennsylvania State University, c2005, [cited $19^{\text {th }}$ March, 2008], $<$ http://www.personal.psu.edu/amk17/BuyerSize.pdf> .

[11] Clark, T. E. - Van Wincoop, E. (2001): Borders and Business Cycles. Journal of International Economics, 2001, vol. 55, no. 1, pp. 59-85. 
[12] Clarke, R. - Davies, S. - Waterson, M. (1984): The ProfitabilityConcentration Relation: Market Power or Efficiency? Journal of Industrial Economics, 1984, vol. 32, no. 4, pp. 435-450.

[13] Chipty, T. - Snyder, C. M. (1999): The Role of Firm Size in Bilateral Bargaining: A Study of the Cable Television Industry. Review of Economics and Statistics, 1999, vol. 81, no. 2, pp. 326-340.

[14] Coffee, J. C. (2005): A Theory of Corporate Scandals: Why the U.S. and Europe Differ. Oxford Review of Economic Policy, 2005, vol. 21, no. 2, pp. 198-211.

[15] Collins, D. W. - Kothari, S. P. (1989): An Analysis of Intertemporal and Cross-Sectional Determinants of Earnings Response Coefficients. Journal of Accounting \& Economics, 1989, vol.11, no. 2-3, pp. 143-81.

[16] Degeorge, F. - Zeckhauser, R. (1993): The Reverse LBO Decision and Firm Performance: Theory and Evidence. Journal of Finance, 1993, vol. 48, no. 4, pp. 1323-1348.

[17] Desai, H. - Hogan, C. E. - Wilkins, M. S. (2006): The Reputational Penalty for Aggressive Accounting: Earnings Restatements and Management Turnover. Accounting Review, 2006, vol. 81, no. 1, pp. 83-112.

[18] Durand, R. - Vargas, V. (2003): Ownership, Organization, And Private Firms' Efficient Use of Resources. Strategic Management Journal, 2003, vol. 24, no. 7, pp 667-675.

[19] Dyl, E. A. (1989): Agency, Corporate Control And Accounting Methods: The LIFOFIFO Choice. Managerial and Decision Economics, 1989, vol. 10, no. 2. pp. 141-145.

[20] Evans, J. - Poa, M. - Rath, S. (2005): The Financial and Governance Characteristics of Australian Companies Going Private. International Journal of Business Studies, 2005, vol. 13, no.1, pp.124.

[21] Fama, E. F. - French, K. R. (2000): Forecasting Profitability and Earnings. Journal of Business, 2000, vol. 73, no. 2. pp. 161-175.

[22] Fee, C. E. - Thomas, S. E. (2003): Sources of Gains in Horizontal Mergers: Evidence from Customer, Supplier, and Rival Firms. [on-line], Social Science Research Network, $23^{\text {rd }}$ May 23, 2003, [cited $13^{\text {th }}$ March, 2008], <http://ssrn.com/abstract=384900>. 
[23] Ghosh, A. - Moon, D. (2005): Auditor Tenure and Perceptions of Audit Quality. Accounting Review, 2005, vol. 80, no. 2, pp. 585-612.

[24] Hawawini, G. - Subramanian, V. - Verdin, P. (2003): Is Performance Driven by Industry- or Firm-specific Factors? A New Look at the Evidence. Strategic Management Journal, 2003, vol. 24, no. 1, pp 1-16.

[25] Hertzel, M. - Lemmon, M. - Linck, J. S. - Rees, L. (2002): LongRun Performance Following Private Placements of Equity. Journal of Finance, 2002, vol. 57, no. 6, pp. 2595-2617.

[26] Holl, P. (1975): Effect of Control Type on the Performance of the Firm in the U.K. Journal of Industrial Economics, 1975, vol. 23, no. 4, pp. 257-271.

[27] Jagannathan, R. - McGrattan, E. - Scherbina, A. (2000): The Declining U.S. Equity Premium. Federal Reserve Bank of Minneapolis Quarterly Review, 2000, vol. 24, no. 4, pp. 3-19.

[28] Jain, B. A. - Kini, O. (1994): The Post-Issue Operating Performance of IPO Firms. Journal of Finance, 1994, vol. 49, no. 5, pp. 16991726.

[29] Kirchmaier, T. - Grant, J. (2005): Corporate ownership structure and performance in Europe. European Management Review, 2005, vol. 2, no. 3, pp. $231-245$.

[30] Kwon, Y. K. - Newman, D. P. - Suh, Y. S. (2001): The Demand for Accounting Conservatism for Management Control. Review of Accounting Studies, 2001, vol. 6, no. 1, pp. 29-51.

[31] Lieu, P. - Chi, C. (2006): How Much Does Industry Matter in Taiwan? International Journal of Business, 2006, vol. 11, no. 4, pp. 387-402.

[32] Lowry, M (2003): Why does IPO volume fluctuate so much? Journal of Financial Economics. 2003, vol. 67, no. 1, pp. 3-40.

[33] Machlup, F. - Taber, M. (1960): Bilateral Monopoly, Successive Monopoly, and Vertical Integration. Economica, New Series. 1960, vol. 27, no. 106, pp. 101-119.

[34] MacKinnon, J. G. - White, H. (1985): Some heteroskedasticityconsistent covariance matrix estimators with improved finite sample properties. Journal of Econometrics, 1985, vol. 29, no. 3, pp. 305325. 
[35] Mehra, R. - Prescott, E. C. (2003): The equity premium in retrospect. In: Constantinides, G.M. - Harris, M. - Stulz, R. (ed.): Handbook of the Economics of Finance. Amsterdam, Elsevier, 2003, pp. 887-936.

[36] Mull, R. H. - Winters, D. B. (1997): IPOs, Public Market Access, And Firm Capital Structure. Journal of Economics and Finance. 1997, vol. 20, no. 4 (Supplemental Issue), pp. 99-108.

[37] Nofsinger, J. R. (2005): Social Mood and Financial Economics. Journal of Behavioral Finance, 2005, vol. 6, no. 3, pp. 144-160.

[38] Peristiani, S. - Hong, G. (2004): Pre-IPO Financial Performance and Aftermarket Survival. Current Issues in Economics and Finance, 2004, vol. 10, no. 2, pp. 1-7.

[39] Penman, S. H. (2003): The Quality of Financial Statements: Perspectives from the Recent Stock Market Bubble. Accounting Horizons, 2003, vol. 17, Supplement, pp. 77-96.

[40] Ritter, J. (2005): Economic growth and equity returns. Pacific-Basin Finance Journal, 2005, vol. 13, no. 5, pp. 489- 503

[41] Schargrodsky, E. (2001): Do Publicly Traded Firms Price Differently from Private Firms? [on-line], [on-line], Social Science Research Network, 28 ${ }^{\text {th }}$ February, 2001, [cited $19^{\text {th }}$ June, 2008], $<$ http://ssrn.com/abstract=269492>.

[42] Schmalensee, R. (1985): Do Markets Differ Much? American Economic Review, 1985, vol. 75, no. 3, pp. 341-351.

[43] Schreiner, A. (2007): Equity Valuation Using Multiples: An Empirical Investigation. Dissertation no. 3313. Wiesbaden, Deutscher Universitäts-Verlag, 2007.

[44] Snyder, C. M. (1995): A Dynamic Theory of Countervailing Power. RAND Journal of Economics, 1995, vol. 27, no. 4, pp. 747-769.

[45] Tucker, J. W. - Zarowin, P. A. (2006): Does Income Smoothing Improve Earnings Informativeness? Accounting Review, 2006, vol. 81, no. 1, pp. 251-270.

[46] Valentincic, A. - Mramor, D. (2000): Forecasting the Liquidity of Very Small Private Companies. [on-line], Social Science Research Network, 2000, [cited $1^{\text {st }}$ September, 2008], $<$ http://ssrn.com/abstract=247328> . 


\title{
Performance of Quoted and Non-quoted Companies in the Europe
}

Tomáš BUUS

\begin{abstract}
Using 4-dimensional panel data (time, industry, country, companies) we examine the differences between European quoted and non-quoted companies at the level financial performance and some financial ratios. We find that quoted companies perform significantly better not only in terms of profit, but also in terms of cash flow generation. We also find some interesting differences in financial structure, liquidity and collection and credit period, not only from the perspective of quotation, but also between European regions (thus different trade habits), e.g. significantly longer credit period and collection period for countries with more relaxed trade habits (Spain, Italy, France). Our findings have some indirect implications for agency theory, for view of different accounting standards conservatism and earnings management, as well as (mainly) for business and stock valuation and financial planning.
\end{abstract}

Key words: Profitability, quotation, agency cost.

JEL classification: G12, G14, G39. 